\title{
INVESTIGATION OF PRESENCE OF METHICILLIN RESISTANT STAPHYLOCOCCI IN STUDENTS OF THE FACULTY OF VETERINARY MEDICINE AT THE UNIVERSITY OF BELGRADE
}

\author{
Milan Rađenović ${ }^{*}$, Jelena Ašanin ${ }^{2}$, Ksenija Aksentijević ${ }^{1}$, Dušan Mišić ${ }^{1}$ \\ ${ }^{1}$ University of Belgrade, Faculty of Veterinary Medicine, Belgrade, Serbia \\ ${ }^{2}$ University of Belgrade, Innovation Center of the \\ Faculty of Technology and Metallurgy, \\ Belgrade, Serbia
}

\section{Abstract}

Resistance to methicillin in staphylococci is considered to be one of the most dangerous forms of bacterial resistances to antibiotics. Methicillinresistant staphylococci (MRS) are zoonotic agents which cause local and systemic infections in humans and animals, often with a fatal outcome due to the absence of adequate antibiotic therapy. People colonized with strains of MRS are asymptomatic carriers and reservoirs of these strains in human populations. The aim of this research was to determine the prevalence of strains of MRS among clinically healthy students of the Faculty of Veterinary Medicine in Belgrade. The study was conducted on 100 volunteers: 62 males and 38 females. Given that staphylococci are expected to be found in the highest percentage in the nose and on the armpit skin, the swabs were taken from these regions of each person. Blood agar was innoculated immediately on taking the swabs After the incubation and isolation, the staphylococci were identified to species level. Their susceptibility to methicillin was tested in a disk-diffusion test with cefoxitin. All strains which were found to be resistant to cefoxitin were investigated for the presence of mecA gene with PCR. Staphylococci were isolated in 146 out of the 200 swabs taken: there were 79 nose swabs and 67 axillar swabs positive for these bacteria. Seventeen isolates were resistant to cefoxitin and the presence of the mecA gene was confirmed in seven, four of which were taken from the nose and three from the axillary region. The results of this research show that, being $6 \%$, the prevalence of mecA-positive staphylococci in the

${ }^{1 *}$ E-mail: dusan@ $@$ vet.bg.ac.rs 
population of clinically healthy students of veterinary medicine is significant. The percentage of methicillin-resistant staphylococci was higher in nose than in the axillar region of the students.

Key words: staphylococci, methicillin resistance, prevalence, asymptomatic carriers

\title{
PRISUSTVO SOJEVA STAFILOKOKA REZISTENTNIH NA METICILIN KOD STUDENATA FAKULTETA VETERINARSKE MEDICINE UNIVERZITETA U BEOGRADU
}

\author{
Milan Rađenović ${ }^{1}$, Jelena Ašanin ${ }^{2}$, Ksenija Aksentijević ${ }^{1}$, Dušan Mišić \\ ${ }^{1}$ Fakultet veterinarske medicine Univerziteta u Beogradu, Beograd, Srbija \\ ${ }^{2}$ Inovacioni centar Tehnološko-metalurškog fakulteta \\ Univerziteta u Beogradu, Beograd, Srbija
}

\section{Kratak sadržaj}

Rezistencija na meticilin kod stafilokoka smatra se jednim od najopasnijih oblika rezistencije bakterija na antibiotike. Sojevi meticilin rezistentnih stafilokoka (MRS) pripadaju zoonotskim agensima i uzročnici su lokalnih i sistemskih infekcija kod ljudi i životinja, često sa fatalnim ishodom zbog nedostatka efikasne terapije. Ljudi kolonizovani sojevima MRS su asimptomatski nosioci i predstavljaju rezervoare ovih sojeva u humanoj populaciji. Cilj ovog istraživanja je bio da se utvrdi prevalencija izolata MRS kod klinički zdravih studenata Fakulteta veterinarske medicine u Beogradu. U istraživanje je bilo uključeno 100 studenata - dobrovoljaca, 62 muškog i 38 ženskog pola. Brisevi su uzimani iz nosa i pazuha zato što su stafilokoke u najvećem procentu zastupljene u tim regijama. Brisevi su odmah zasejavani na krvni agar. Nakon inkubacije i izolacije, izvršena je identifikacija stafilokoka do vrste. Ispitivanje osetljivosti stafilokoka na meticilin izvedeno je primenom disk difuzione metode sa cefoksitinom. Svi sojevi rezistentni na cefoksitin ispitani su na prisustvo mecA gena metodom lančane reakcije polimeraze (PCR). Od ukupno 200 uzetih briseva izolovano je 146 izolata stafilokoka, 79 iz briseva nosa i 67 iz briseva pazušne regije. Kod 17 izolata ustanovljena je rezistencija na cefoksitin, a kod 7 je utvrđeno prisus- 
tvo mecA gena. Četiri mecA pozitivna izolata su poticala iz briseva nosa, a 3 sa kože pazušne regije. Utvrđena prevalencija meticilin-rezistentnih stafilokoka kod klinički zdravih studenata Fakulteta veterinarske medicine od $6 \%$, procenjena je kao značajna. Veća učestalost stafilokoka rezistentnih na meticilin ustanovljena je na sluzokoži nosa u odnosu na kožu pazuha.

Ključne reči: stafilokoke, rezistencija na meticilin, prevalencija, asimptomatski nosioci

\section{INTRODUCTION}

The resistance to methicillin was first detected in Staphylococcus aureus in Great Britain in 1961 (Ašanin et al., 2012; Ćirković et al., 2015; Kluytmans et al., 1997). This type of resistance emerged only two years after methicillin, a semisynthetic penicillin preparation resistant to an inducible enzyme - penicillinase, was introduced into clinical practice. The same year the term MRSA (methicillin-resistant Staphylococcus aureus) was coined, which is still in use, although methicillin is not used for the detection of this type of resistance any more. The most frequent mechanism of resistance to methicillin is the acquisition of mecA gene $(2.1 \mathrm{~kb})$, which is part of the mobile genetic element of the staphylococcal cassette chromosome mec (SCCmec) (Oliveira et al., 2002; Schito, 2006, De Brito et al., 2015). MecA gene codes for the synthesis of the new penicillin-binding protein, $\mathrm{PBP} 2 \mathrm{a}(78 \mathrm{kD})$, which has low affinity towards methicillin (Oliveira et al., 2002). The production of PBP 2a results in the resistance of staphylococci towards all beta-lactam antibiotics (penicillins, betalactams with beta-lactamase inhibitors, cephems excluding cephalosporins which are active against MRSA strains - ceftaroline and ceftobiprole - and carbapenems) (CLSI, 2016; EUCAST, 2016). Besides mecA genes, staphylococcal cassette chromosome carry many resistance genes to other antibiotics, which is why methicillin-resistant staphylococci (MRS) are considered multidrugresistant pathogens that cause local and systemic infections in humans and animals with frequent fatal outcome due to the absence of efficacious antibiotics. In 2011 in MRSA strains isolated from cattle and humans another form of mecA gene, mec $\mathrm{A}_{\mathrm{LGA251}}$ homologue (García-Álvarez et al., 2011), named mec $\mathrm{C}$ gene (Ito et al., 2012) was detected, which was impossible to be done earlier with the protocols for the detection of mecA genes. This discovery has raised a question of relevancy of data about the prevalence of MRS on the earth, since it has been clear that there must be more than it was thought.

Although the application of strict control measures in certain countries of the EU, such as Denmark and Sweden, has led to the decrease in the incidence 
of infections caused by MRSA in humans to less than $1 \%$, it is estimated that the global epidemiological situation concerning the emergence and spread of MRSA strains in the 20th century has dramatically worsened. Thus the resistance of staphylococci to methicillin is considered to be one of the most dangerous and most widespread resistances to antibiotics of all (David et al., 2010). Besides well-known categories, HA-MRSA (healthcare-associated MRSA) and CA-MRSA (community-associated MRSA), there is a third one - LA-MRSA (livestock-associated MRSA). The existence of asymptomatic carriers is of utmost importance in the epidemiology of MRS. These are people and animal which are not diseased, but are colonised by MRS strains, which means that these bacteria are part of the microbiota of the skin and mucous membranes. Asymptomatic MRS carriers are sources of infection for people who are most at risk of developing disease. Given that these asymptomatic carriers are clinically healthy people, it is difficult to identify them and impossible to treat by any means. Asymptomatic carriers may be colonised by any of the listed MRSAs (HA-MRSA, CA-MRSA and LA-MRSA). Due to the increasing number of reports concerning the transmission from animals to people, MRSA strains have been considered zoonotic infective agents and are in many countries governed by legislation, which precisely define procedures of their detection, prevention of emergence and spread, and how to combat infections. Special attention was paid to the MRSA strain which belongs to the clonal complex 398 (CC398), known by its jargon name - 'the pig clone'. Clone MRSA CC398 colonises pigs, which almost never become ill and as asymptomatic carriers are source of human infection (Lewis et al., 2008). It is thought that CC 398 strain has spread through farm workers and their family members to people in cities and can now be found in hospitals in the EU, in intensive-care units, where it causes $15 \%$ of the MRSA infections.

\section{MATERIAL AND METHODS}

The research was conducted on a hundred students of the Faculty of Veterinary Medicine in Belgrade. There were 62 males and 38 females aged from 19 to 31 years. Swabs were taken from students of all years, from the 1st to the 6th, as well as from interns. From each student two swabs were taken: one from the nose and the second from the skin of the axillary region. In addition, each person was asked to fill in the questionnaire connected with the research. The questions were divided into five groups. The first group dealt with the student's pet (if they had any). The second group of questions included anamnestic data on the previous use of antibiotics, and the third one information 
about hospitalisation and visits to the hospital. The last two question groups concerned contact with farm animals (cattle and/or pigs) which are potential carriers of LA-MRSA.

Blood agar (Columbia agar with 5\% sheep blood, bioMérieux, France) plates were inoculated for the isolation of staphylococci immediately after the swabs were taken and the petri dishes were incubated for $18-24$ hours at $37^{\circ} \mathrm{C}$. Commercial tests, ID32 STAPH (bioMérieux, France) and BBL Crystal GramPositive ID Kit (Becton Dickinson, USA) were used for the identification of the isolates.

Phenotypic research on the resistance to methicillin was performed by disc diffusion method on Mueller Hinton agar (bioMérieux, France) using antimicrobial-susceptibility test discs of cefoxitin $(30 \mu \mathrm{g})$ (Becton Dickinson, USA). The results were interpreted according to the guidelines proposed by EUCAST (EUCAST, 2016). The inoculum density of the strains tested was approximately $1-2 \times 10^{8} \mathrm{CFU} / \mathrm{mL}$, which is equivalent to $0.5 \mathrm{McF}$ arland standard.

All isolates resistant to cefoxitin were tested for the presence of mecA and $m e c C$ genes using the PCR technique. Staphylococcus spp. DNA extraction was performed following the protocol proposed by the European Union's reference laboratory for antimicrobial resistance - EU Reference Laboratory-Antimicrobial resistance, Faculty of Veterinary Medicine, Lisbon, Portugal.

According to the protocol for the detection of mecA gene (Isenberg, 2004), the length of PCR product was $533 \mathrm{bp}$. The sequence of the primers (Invitrogen, USA) for the amplification of $533 \mathrm{bp}$ region of mecA gene was the following: primer 1 (5'-AAA ATC GAT GGT AAA GGT TGG C-3') and primer 2 (5'-AGT TCT GCA GTA CCG GAT TTG C-3') each in final concentration of $0.25 \mu \mathrm{M}$. All deoxyribonucleoside triphosphates (Thermo Scientific) were used in concentration of $200 \mu \mathrm{M}$. In addition, the following reagents were used: PCR buffer $1 \mathrm{x}, 1.5 \mathrm{mM} \mathrm{MgCl}_{2}$ and $5 \mathrm{U}$ TaqDNA polymerase (Thermo Scientific).

The procedure started by initial denaturation at $94^{\circ} \mathrm{C}$ for 5 minutes, followed by 40 cycles of denaturation at $94^{\circ} \mathrm{C}$ for 30 seconds, annealing at $55^{\circ} \mathrm{C}$ for 30 seconds and extension at $72^{\circ} \mathrm{C}$ for 1 minute, and, final extension at $72^{\circ} \mathrm{C}$ for 5 minutes in the thermocycler (Eppendorf, Germany). The After electrophoresis in $1.5 \%$ agarose gel with ethidium bromide in $1 \mathrm{x}$ TBE buffer at $100 \mathrm{~V}$, PCR products were visualised on the UV transilluminator (Vilber Lourmat, Germany). Two reference strains were used for quality control: Staphylococcus aureus ATCC 43300 as the positive control, and as the negative one Staphylococcus aureus ATCC 25923.

Isolates which were negative for the presence of $m e c A$ genes were assessed 
for the presence of mecC gene using the protocol described by Garcia-Alvarez et al. in 2011. The primers produced by Invitrogen (USA), with the following sequences: FW 5' -TCACCAGGTTCAAC(Y)CAAAA -3' and RW 5' CCTGAATC(W)GCTAATAATATTTC - 3 ' were used. The length of the targeted PCR products was $356 \mathrm{bp}$. The mecC-positive $S$. aureus strain was used as a positive control, obtained from courtesy of the Department of microbiology of the Veterinary University in Vienna (Austria).

\section{RESULTS}

Staphylococci were isolated from 146 out of 200 swabs (79 isolates from the nose and 67 from the axilla). Using the disc diffusion method, resistance to cefoxitin was detected in 17 isolates, i.e. in 12 nose and 5 axillary swabs. PCR technique detected mecA gene in 7 isolates, which were identified as S. epidermidis $(\mathrm{n}=4), S$. aureus $(\mathrm{n}=2)$ and $S$. haemolyticus $(\mathrm{n}=1)$. Four mecA-positive isolates were from the nose and three from the armpit. Six out of seven mecApositive isolates originated from males. Five MRS isolates was identified in 3 rd-year students and one in a 1st-year and a 4th-year student.

The diameters of the growth inhibition zone around the cefoxitin discs in the disc diffusion test, which were the criteria for the suspicion that the isolates tested were methicillin-resistant, are presented in Table 1. In addition, in Table 1 the results of the biochemical identification of the isolates and the molecular (PCR) research. In one student, methicillin-resistant S. epidermidis was found both in the nose and in the axillary region. The prevalence of MRS isolates detected in the students of the Faculty of Veterinary Medicine was 6\% (Figure 1).

Concerning ten isolates, the diameter of growth inhibition zone around the cefoxitin disc was less than $25 \mathrm{~mm}$ for coagulase-negative staphylococci and less than $22 \mathrm{~mm}$ for $S$. aureus, which is why they were, in accordance with the recommendations of EUCAST, considered resistant to methicillin. However, with the PCR technique in those isolates the presence of mecA and mecC genes was not detected. 
Table 1. Species of staphylococci, their origin, results of cefoxitin disk diffusion test and presence of methicillin resistance genes by PCR

\begin{tabular}{|c|c|c|c|c|c|}
\hline \multirow{2}{*}{$\begin{array}{l}\text { Isolate } \\
\text { num- } \\
\text { ber }\end{array}$} & \multirow[t]{2}{*}{ Species } & \multirow[t]{2}{*}{ Origin } & \multirow{2}{*}{$\begin{array}{c}\text { Growth inhibition } \\
\text { zone diameter }(\mathrm{mm}) \\
\text { cefoxitin disk }(30 \mu \mathrm{g})\end{array}$} & \multicolumn{2}{|c|}{$\begin{array}{c}\text { Resistance } \\
\text { genes }\end{array}$} \\
\hline & & & & mecA & mecC \\
\hline 1 & S. vitulinus & nose & 15 & - & - \\
\hline 2 & S. aureus & nose & 18 & - & - \\
\hline 3 & S. haemolyticus & nose & 20 & + & NT \\
\hline 4 & S. aureus & nose & 17 & - & - \\
\hline 5 & S. aureus & axillary region & 20 & - & - \\
\hline 6 & S. aureus & nose & 14 & - & - \\
\hline 7 & S. aureus & nose & 16 & - & - \\
\hline 8 & S. aureus & nose & 20 & - & - \\
\hline 9 & S. epidermidis & nose & 19 & - & - \\
\hline 10 & S. epidermidis & axillary region & 20 & + & NT \\
\hline 11 & S. epidermidis & nose & 23 & + & NT \\
\hline 12 & S. epidermidis & axillary region & 17 & + & NT \\
\hline 13 & S. epidermidis & axillary region & 18 & + & NT \\
\hline 14 & S. aureus & nose & 19 & + & NT \\
\hline 15 & S. aureus & nose & 20 & + & NT \\
\hline 16 & S. aureus & nose & 20 & - & - \\
\hline 17 & S. haemolyticus & axillary region & 23 & - & - \\
\hline
\end{tabular}

${ }^{\star}$ NT- not tested for mecC

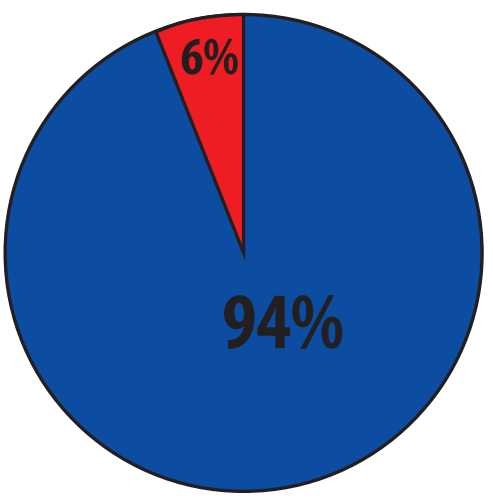

$\square$ Students with no MRS strains detected

Asymptomatic carriers

Figure 1. The percentages of asymptomatic carriers of methicillin-resistant staphylococci (MRS) among students of Belgrade University, Faculty of Veterinary Medicine 


\section{DISCUSSION}

The prevalence of staphylococci resistant to methicillin can vary significantly among various studies and may result from genuine differences in the prevalence of MRSA in the populations tested (Ćirković et al., 2015). The complete control of the presence of certain clones of MRS in the people of the whole country is virtually impossible. However, monitoring the presence of MRS in certain populations may be the first step in the battle against the high prevalence of methicillin-resistant staphylococci. This research was based on that principle, with the aim of detecting the number of asymptomatic carriers of MRS strains in a small population of the students of the Faculty of Veterinary Medicine in Belgrade. From the investigation conducted on 100 students, the data on the prevalence of staphylococci resistant to methicillin in our nearest surrounding can be obtained.

The nasal mucous membrane is considered the primary location colonised by MRS strains (Rohr et al., 2004), which has been confirmed in our study. MRS may colonise other locations on the human body, despite not having been found on the nasal mucosa. In research performed in England, it was discovered that the colonisation of the pharynx with MRSs $(72 / 635$, or $11.3 \%)$ occurs more frequently than that of the nose $(59 / 635,9.3 \%)$ or other body parts (Bignardi et al., 2009). Some authors consider that there are three types of asymptomatic carriers of CA-MRSA in a population (Kluytmans et al., 1997). According to these, $20 \%$ of asymptomatic carriers are colonised incessantly, whilst in $60 \%$ the presence of MRSA happens periodically. The rest of the asymptomatic carriers, $20 \%$, are rarely colonised with MRS. The research done by Lim et al. (2006) suggests that persistent asymptomatic MRS carriers who have these in the nose are protected from the colonisation with new $S$. aureus strains.

Statistically, MRSs were detected in $6 \%$ of the students of the Faculty of Veterinary Medicine in Belgrade. This is significantly lower prevalence in comparison to the countries with high prevalence of MRS, such as in India, where it has been detected to be $41 \%$ (Joshi et al., 2013). The highest prevalence of MRS was detected in hospital environments, which was confirmed by multiple studies. For example, in a hospital in Portugal 54 strains of $S$. aureus were isolated and in $14(25.9 \%)$ the mecA gene was detected (Espadinha et al., 2013). Out of the 1,195 patients of the Saint Louis hospital in USA, 31.8\% were colonised with MRS (Fritz et al., 2009).

The investigation completed by researchers in Serbia (Ćirković et al., 2013) revealed a low prevalence of MRSA strains: it was $0.37 \%$ in 533 second-, third- 
and fourth-year students of the School of Medicine in Belgrade. It is to be underlined that in this research coagulase-negative staphylococci (CoNS) were not taken into consideration. However, our investigation was performed on fewer people but the prevalence of MRSA was $2 \%$. Due to direct contacts with hospital patients, higher-year students of the School of Medicine were at considerably higher risk of being colonised by MRSA strains. By contrast, according to the survey, students of the Faculty of Veterinary medicine had no risky contacts, thus it remains unclear what is the reason of higher prevalence of MRSA strains in this population compared to medical students.

Investigation into the presence of MRSA strains in the nose of healthy students of the Medical Faculty in Czech Republic detected as many as 32\% 1styear and 30\% 5th-year students asymptomatically colonised with MRSA (Holý et al., 2015).

Similar research to ours was undertaken in Mexico, when nasal and pharyngeal swabs were collected from 21-year old clinically healthy volunteers (Hamdan-Partida et al., 2013). None of them had been hospitalised before. Out of 1,039 staphylococci isolated, 131 (12.61\%) were methicillin-resistant. Unlike in our research, in which the majority of MRS were isolated from the nose, in the one conducted by Hamdan-Partida et al. (2013) the numbers of MRS isolates from the nose and pharynx were roughly equal.

According to the survey, 5 out of the 6 examined people from whom MRS were isolated, had immediate contact with farm animals (cattle and swine) and domestic pets (dogs and cats). None of them came into either permanent or periodic contact with people who work at hospitals or some other healthcare facilities. One person had contact neither with pets nor with farm animals. As stated in the questionnaires, none of the persons with MRS had taken any antibiotics or had visited hospitals in the previous six months. Three persons harbouring MRS were in direct contact with family members or friends who had taken antibiotics in the recent past. Thus, it is confirmed that all people are susceptible to MRS (Mišić, 2013).

More than 50\% isolates which proved to be resistant to methicillin in the disc diffusion test were not mecA-positive, which points to the unreliability of the disc diffusion method in the investigation into the resistance of staphylococci towards methicillin.

\section{CONCLUSIONS}

The diameter of growth inhibition zone in the disc diffusion method may serve only as a tool for arising suspicion that there is resistance to methicillin 
in routine diagnostic. The prevalence of MRS in clinically healthy students of the Faculty of Veterinary Medicine, which was 6\%, was considered to be significant. The incidence of methicillin-resistant staphylococci was higher on the nasal mucous membrane than in the axillary region.

\section{ACKNOWLEDGEMENTS}

This investigation was supported by a grant from the Ministry of Education, Science and Technological Development of the Republic of Serbia, Project No. 31079.

\section{REFERENCES}

1. Ašanin J., Aksentijević K., Zdravković N., Ašanin R., Mišić R.: Detection of PBP2a (penicillin-binding protein 2a) and mecA gene in methicillin resistant staphylococci originated from animals. Acta Veterinaria, 62, 4, 375-384, 2012.

2. Bignardi GE., Lowes S.: MRSA screening: throat swabs are better than nose swabs. J Hosp Infect, 71, 373- 374, 2009.

3. Clinical and Laboratory Standards Institute (CLSI): Performance Standards for Antimicrobial Susceptibility Testing, M100S, 26th Edition. Wayne, PA, Clinical and Laboratory Standards Institute, 2016.

4. Ćirković I., Stepanović S., Skov R., Trajković J., Grgurević A., Larsen AR.: Carriage and Genetic Diversity of Methicillin-Resistant Staphylococcus aureus among Patients and Healthcare Workers in a Serbian University Hospital. PloS ONE, 10, 5, e0127347, 2015.

5. Ćirković I., Đukić S., Vuković D., Stevanović G., Švabić-Vlahović M., Stepanović S.: Nazalno kliconoštvo meticilin-rezistentnog Staphylococcus aureus kod studenata Medicinskog fakulteta Univerziteta u Beogradu. Srpski arhiv za celokupno lekarstvo, 141, 5-6, 349-353, 2013

6. David M.Z., Daum R.S.: Community-Associated Methicillin-Resistant Staphylococcus aureus: Epidemiology and Clinical Consequences of an Emerging Epidemic. Clin Microbiol Rev, 23, 3, 616-687, 2010.

7. De Brito CS., Ludendorff Queiroz L., Amaral de Campos P., Fonseca Batistao DW., Almeida Silva H., Gularte de Agostini G., Filho PPG., Marques Ribas R.: The nares as a CA-MRSA reservoir in the healthy elderly. Rev Soc Bras de Med Trop, 48, 5, 614-616, 2015.

8. Espadinha D., Faria NA., Miragaia M., Lito LM., Melo-Cristino J., Lencastre H.: Extensive Dissemination of Methicillin-Resistant Staphylococcus aureus 
(MRSA) between the Hospital and the Community in a Country with a High Prevalence of Nosocomial MRSA. PloS ONE, 8, 4, e59960, 2013.

9. European Committee on Antimicrobial Susceptibility Testing (EUCAST): Breakpoint tables for interpretation of MICs and zone diameters, Version 6.0.2016. The European Committee on Antimicrobial Susceptibility Testing, 2016.

10. Fritz SA., Epplin EK., Garbutt J., Storch GA.: Skin infection in children colonized with community- associated methicillin-resistant Staphylococcus aureus. J Infect, 59, 6, 394-401, 2009

11. García-Álvarez L., Holden TGM., Lindsay H., Webb CR., Brown DFJ., Curran MD., Walpole E., Brooks K., Pickard DJ., Teale C., Parkhill J., Bentley SD., Edwards GF., Girvan EK., Kearns AM., Pichon B., Hill RLR., Larsen AR., Skov RL., Peacock SJ., Maskell DJ., Holmes MA.: Methicillin-resistant Staphylococcus aureus with a novel mecA homologue in human and bovine populations in the UK and Denmark: a descriptive study. Lancet Infect Dis, 11, 8. 595-603, 2011.

12. Hamdan-Partida A., Sainz-Espuñes T., Bustos-Martínez J.: Characterization and persistence of Staphylococcus aureus strains isolated from the anterior nares and throats of healthy carriers in a Mexican community. J Clin Microbiol, 48, 5, 1701-1705, 2010.

13. Holý O., Vlčková J., Matoušková I., Kolář M.: The prevalence of nasal carriage of Staphylococcus aureus and methicillin-resistant S. aureus (MRSA) among general medicine students of the Palacky University Olomouc. Epidemiol Mikrobiol Imunol, 64, 2, 98-101, 2015.

14. Isenberg HD.: Detection of Methicillin Resistance in Staphylococci by PCR. In: Isenberg HD, Clinical Microbiology Procedures Handbook, Vol. 3, Washington DC USA: ASM Press, 2004, p. 12.5.3.1.

15. Ito T., Hiramatsu K., Tomasz A., de Lencastre H., Perreten V., Holden MTG., Coleman DC., Goering R., Giffard PM., Skov RL., Zhang K., Westh H., O'Brien F., Tenover FC., Oliveira DC., Boyle-Vavra B., Laurent F., Kearns AM., Kreiswirth B., Soo Ko K., Grundmann H., Sollid JE., John JF. Jr., Daum R., Soderquist B., Buistx G.: Guidelines for reporting novel mecA gene homologues. Antimicrob Agents Chemother, 56, 10, 4997-4999, 2012.

16. Joshi S., Ray P., Manchanda V., Bajaj J., Chitnis DS., Gautam V., Goswami P., Gupta V., Harish BN., Kagal A., Kapil A., Rao R., Rodrigues C., Sardana R., Devi KS., Sharma A., Balaji V.: Methicillin resistant Staphylococcus aureus (MRSA) in India: Prevalence \& susceptibility pattern. Indian J med Res, 137, 2, 363-369, 2013.

17. Kluytmans J., Van Belkum A., Verbrugh H.: Nasal carriage of Staphylococcus aureus: epidemiology, underlying mechanisms, and 
associated risks. Clin Microbiol Rev, 10, 3, 505-520, 1997.

18. Lim MS., Marshall CL., Spelman D.: Carriage of multiple subtypes of methicillin- resistant Staphylococcus aureus by intensive care unit patients. Infect Control Hosp Epidemiol, 27, 10, 1063-1067, 2006.

19. Lewis HC., Mølbak K., Reese C., Aarestrup FM., Selchau M., Sørum M., Skov RL.: Pigs as source of methicillin-resistant Staphylococcus aureus CC398 infections in humans, Denmark, Emerg Infect Dis, 14, 9, 1383-1389, 2008.

20. Misic D.: Metode mikrobiološke dijagnostike - ispitivanje osetljivosti bakterija na antibiotike. Beograd, Elit Medica, 2013.

21. Oliveira DC., Tomasz A., de Lencastre H.: Secrets of success of a human pathogen: molecular evolution of pandemic clones of methicillin-resistant Staphylococcus aureus. Lancet Infect Dis, 2, 3, 180-189, 2002.

22. Rohr U., Wilhelm M., Muhr G., Gatermann S.: Qualitative and (semi)quantitative characterization of nasal and skin methicillin-resistant Staphylococcus aureus carriage of hospitalized patients. Int J Hyg Environ Health, 207, 1, 51-55, 2004.

23. Schito GC.: The importance of the development of antibiotic resistance in Staphylococcus aureus. Clin Microbiol Infect, 12, S1, 3-8, 2006.

Primljeno: 05.12.2016.

Odobreno: 25.12.2016. 